\author{
Marek Zgorzelski \\ Department of Geoecology \\ E-mail: zgorzelski@poczta.onet.pl
}

\title{
LADAKH AND ZANSKAR
}

\begin{abstract}
The Himalayan mountain chain is orographically fragmented, both in the east-west and in the north-south directions. The latter area is characterised by a greater landscape diversity, owing to its zonality and the vertical zonation of both climate and vegetation.

In terms of tectonics and orography, and taking into account the prevalent influence of the monsoon and continental climates, the Himalayan mountain system can be divided into two parts - the external arc (southern), that is the Higher (or Great) Himalayas and the internal arc (northern), that is the so-called Trans-Himalayas.

Similarly to the external arc of the Himalayas, the post-glacial relief in the Trans-Himalayas is marginal only. It is an area with a prevalence of denudation (nival, frost, gravitation and eolian) processes. Slopes of tectonic valleys or basins, covered with colourful surface deposits rising as high as even two thirds of their altitude, dominate the landscape.

The Zanskar ridges and the Ladakh range represent a transitional zone between the Transhimalayas and Eastern Karakoram.
\end{abstract}

Key words: geography, Himalayas, Zanskar, Ladakh.

\section{LADAKH AND ZANSKAR IN THE HIMALAYA SYSTEM}

The Himalayan mountain chain is orographically fragmented, both in the east-west and in the north-south directions. The latter area is characterised by a greater landscape diversity, owing to its zonality and the vertical zonation of both climate and vegetation.

In terms of tectonics and orography, and taking into account the prevalent influence of the monsoon and continental climates, the Himalayan mountain system can be divided into two parts - the external arc (southern), that is the Higher (or Great) Himalayas and the internal arc (northern), that is the so-called Trans-Himalayas.

The external arc, which in the east begins with a large, southward gorge of the Yarlung Tsang-po River (Dihang, Brahmaputra) and is closed in the west with the similarly huge gorge of the Indus, is bounded in the south by the Brahmaputra Valley, the Ganges Valley and a vast plain of the Thar Desert. The external arc is separated from the internal one by a complex 
system of valleys and basins, frequently having a tectonic base, including the Yarlung Tsang-po and Sutledge rivers, which then break through the main Himalayan crest. In the west, the northern boundary of the internal arc is marked by the Indus, running in the latitudinal direction, and in the east - by the Tibet Lake District. In general terms, the regional and local climatic conditions in the Himalayas are mainly shaped by masses of monsoon air. Only in the intermonsoon periods the distinct impact of local orographic conditions can be noticed, mainly of the valley system and slope exposure.

Except for its westernmost part, the internal arc (Trans-Himalayas), contrary to popular belief, does not lie in the rain shadow of the higher and more compact external arc. The regime of monsoon rains in the summer depends on the location. The southern slopes of the Himalayas are characterised by the rain regime, while in the Great Himalayas the snow regime prevails. The Trans-Himalayas and areas lying further north are characterised by the rain or rain and snow regime, with the strict snow regime limited to the highest, spatially confined areas. The climatic changes in the Trans-Himalaya occurring in annual cycles are due to a seasonal prevalence of monsoons (in the summer) or climate continentality (in the winter).

Changes in the mezoclimatic features of the Himalayas can also be observed along the west-east axis. They can be explained by the falling precipitation efficiency of the monsoon in the westward direction, which leads to the lessening of the longitudinal range of monsoons. The further west, the smaller the monsoon zone beyond the external arc.

The paradox of the Himalayan climate typical of the external arc is the fact that the pervasive influence of monsoon leads, on the one hand, to the generation and accumulation of huge masses of ice, while on the other hand the warming effect of the air masses raises the upper boundaries of the climatic and vegetation layers and considerably reduces the range of mountain glaciation (Himalayan glaciers are short!). River erosion, mainly caused by floodings following monsoon rains, is the major orographic factor, increased further by the ongoing rising of the massif. Unlike other high mountains, the relief of the Himalayas is only slightly post-glacial in character. V-shaped valleys, with incisions reaching as deep as several thousand metres, are the dominant form of landscape in the Outer Himalayas.

Going northward from the Himalayan foothills - the Hindustan Valley - we reach the zone of Himalayan hills, represented by the Shiwalik and Mahabharat ranges. The Shiwalik range, with a width between 10 and 40 $\mathrm{km}$, and peaks rising not higher than 2000 metres a.s.l., intersected with several tectonic and erosion basins, runs along the nearly entire Himalayan chain. The other range, reaching a width up to $60 \mathrm{~km}$, with peaks rising from 1800 t0 2400 metres a.s.l., and exceeding 4500 metres a.s.l. in the western part, is the Lower Himalaya chain, also referred to as the Mahabharat. These mountains are intersected by deep gorges of the numerous rivers. Further north, the Lower Himalayas border the Great Himalayas, with elevations reaching one average 6000 metres a.s.l. 
North of the Great Himalayas lies the area of interconnected basins or longitudinal river valleys which in their lower courses break through the southern arc of the Himalayan chain. Beyond them extend the TransHimalayas, composed of numerous mountain ranges separated by valleys and basins, in most cases of tectonic origin. The largest one, the Yarlung Tsang-po valley in the eastern part, intersects the range into the Southern Trans-Himalayas and the Northern Trans-Himalayas. It must be observed, though, that the former mountain chain belongs to the tectonic system of the Great Himalayas, while the latter - to the Himalayas Proper, characterised by different landscape features than in the Great Himalayas.

The following orographic units can be distinguished in the Himalayan chain, going from the east to the west: Eastern Himalayas, Bhutan Himalayas, Sikkim Himalayas, Central Himalayas (also called the High, Great or Nepal Himalayas), Garhwal Himalayas, Western Himalayas.

In the Trans-Himalayas, that is within the northern (internal) arc of the Himalayan mountain complex, two differently formed orographic areas can be distinguished. Its eastern and some of the central parts do not show any distinct orientation of the folded ridges; it is more of a system of basins bounded by mountains and connected with the gorge parts of the river valleys. Many intermontane basins and river gorges have a tectonic base, with peaks which seldom rise above $6500 \mathrm{~m}$ a.s.l. The peaks in the central and western parts of the Trans-Himalayas show a more distinct orientation, along the main east-west axis, which starts with the Kanjiroba Himal mountain chain, to develop into the compact Kailash range. The Zanskar range, marking the end of the Trans-Himalayas in the west, together with the Ladakh mountains makes up a transitional zone between the TransHimalayas and East Karakoram (a part of the tectonic mountain system of Southern Tibet). The Trans-Himalayas can also be divided into the eastern and central monsoon part and the dry, western part (Zanskar).

Similarly to the external arc of the Himalayas, the post-glacial relief in the Trans-Himalayas is marginal only. It is an area with a prevalence of denudation (nival, frost, gravitation and eolian) processes. Slopes of tectonic valleys or basins, covered with colourful surface deposits rising as high as even two thirds of their altitude, dominate the landscape. The muddy valley and basin floors are covered with bugor fields, with overlaying huge barchan complexes.

The landscape shows a prevalence of steppe plant formations (on the slopes) and wetland formations (at the basin bottoms). Forests used to be found at the bottoms of the river valleys only in the eastern part of the region. The Zanskar and Kailash ranges are woodless.

\section{TRANSITIONAL ZONE BETWEEN LADAKH AND ZANSKAR}

Although the two mountain groups belong to different tectonic units, the Zanskar is a part of the Trans-Himalayas, while the Ladakh and the 
Karakoram have their extensions in the rangers of southern Tibet and are intersected by the rift valley of the Indus River, the remaining components of the natural system (climate, relief features, slope cover properties, types of the plant cover) are very similar both in Zanskar and Ladakh. At the same time, Zanskar and Ladakh are characterised by substantial landscape differences as compared to the Himalayas and the Karakoram. This provides the ground to consider the areas in question as a separate physio-geographical entity, combining several tectonic units.

\section{LADAKH AND ZANSKAR}

Between the highest mountain ranges of the world - the Himalayas and the Karakoram - stretches the geographical region of Little Tibet. This region is sometimes referred to as Shangri-La, the Land of Happy People. It is also dubbed as the Moon Country. In the $7^{\text {th }}$ century, the Chinese traveller Hiuan Tsang called it Ma-Lo-Pho - the Red Country. It was also known as Ripul - the Mountainous Country. The name of Ladwak, Land Under the Pass, gave the rise to the current name referring to the Kingdom of Ladakh.

Although one will not find it on the political map of the world, the Kingdom of Ladakh is a reality. It has no army, police, authorities, own currency or other attributes of statehood. It stretches along the upper part of the Indus River and the slopes of the Zanskar and Ladakh ranges, even though its boundaries are rather fluid. Ladakh does have a ruling monarch and enjoys some autonomy within the power system of the Indian province of JammuKashmir. The capital city is Leh.

Owing to its geographical location, the area has been practically inaccessible for ages. Contemporarily, getting there is not always easy. Travellers bound for the city of Leh can take one of the three roads. One leads from Srinagar, situated in the Kashmir Basin, through the Himalayan pass of Zoji La (3 529 metres a.s.l.). The second roads leads from Manala, a city in the Indian province of Himachal Pradesh, across the high passes of Rhotang (3 960 metres a.s.l.) and Baralacha (4 650 metres a.s.l.) in the crest of the Great Himalayas, and Tanglang (5 429 metres a.s.l.) in the main ridge of the Zanskar range. The third sky-high route leads from China across the Karakoram pass (5 575 metres a.s.l.), the Shyok valley and Khardung Pass (5 600 metres a.s.l.) in the Ladakh range.

The Land Under the Passes has been divided into two administrative units, with centres of local authorities in Kargil and Leh. In physio-geographical terms, six regions can be distinguished. Central Ladakh extends from Phyang in the north to Chemre in the south. To the east lies Rong, where the Indus Valley reaches an altitude of $4000 \mathrm{~m}$ a.s.l. and the climate is much colder than in central Ladakh. Rupsho is an open plain, very dry and cold, which lies at an altitude of $4000-5000 \mathrm{~m}$ a.s.l., to the south-west of the Indus River. The small valley of Tangse, situated east of the Indus 
valley and surrounded by mountains with peaks above $4500 \mathrm{~m}$ a.s.l. is the fourth region, while the fifth comprises the mountain chains of Zanskar with the highest peaks of Nun (7 $135 \mathrm{~m}$ a.s.l.) and Kun (7 $070 \mathrm{~m}$ a.s.l.), whose subsequent, longitudinal ranges are separated by the valleys of the Sur, Zanskar and Markhi rivers. The sixth region is the warm Nubra valley situated north of Leh at the Karakoram foothills, famous for its apple and peach orchards and hot springs. It is one of the sources of salt used to prepare Tibetan tea.

Due to the natural barriers, the native inhabitants of Ladakh have largely retained their cultural and religious identity. However, the progress of civilisation however cannot be stopped and the newcomers from Kashmir begin to dominate in many areas, having gained control over trade, crafts and services. The new cultural patterns are imported by the densely stationed Indian army, while the rapidly developing tourism can soon change the face of the entire region. At the same time, Ladakh still remains a country of wild mountains, untamed rivers and proud, determined and persevering people. It is a country permeated by the teachings of the Buddha and beliefs in demons, shrouded in a veil of mystery of rituals celebrated in the ubiquitous Lama monasteries.

The feature that Ladakh and Zanskar have in common is the extremely dry climate in the mountainous areas, which is the reason why the few existing glaciers can be found only in the hilltop and summit areas. Valley glaciers cannot be found here, whereas wall-sided or slope glaciers can only be encountered in the highest parts of the mountains. Mountain slopes are strongly degraded and covered with a thick waste mantle. The extremely varied relief has been formed as a result of the gravitational movements of the mantle and water erosion, which, during the short precipitation period, exerts a profound influence on the slope formation.

The upper, longitudinal section of the Indus valley, situated at an altitude of approximately 3000 metres a.s.l., forms the region's orographic axis. Zanskar constitutes the southern part of this area, with peaks rising above 7000 metres a.s.l. The individual mountain groups of Zanskar are separated from one another by deeply incised valleys with very steep slopes. In the north, the Indus valley is bounded by the Ladakh range, whose summits are slightly higher than 6000 metres a.s.l. The Zanskar mountains were folded as several parallel ranges, for the most part running from the southeast to the north-west direction, separated by river valleys.

The Ladakh range, stretching between the Indus and Shyok valleys, is made up of three parallel crests, and each rising higher from the Indus river. The highest crest is the most extended one, intersected by many asymmetric dry valleys, linked to the Shyok valley.

The region's climate must have recently changed dramatically, over a short period of time. This is evidenced by omnipresent, young alluvial cones of huge sizes. Another proof is the filling of the valleys to an unimaginable extent, standing in no proportion to the usual precipitation rate in the area 
and the ice masses typically encountered in the region. Even short valleys of little more than 10 kilometres in length, are filled in with gravel deposits, reaching several hundred metres in depth. In Ladakh, the deposit floors of the tributary valleys overhang the floors of the main valleys (e.g. over the valleys of the Shyok and Indus rivers), and the resultant steps with a height of several hundred metres (500-800) are built from river deposits. This is not, however, caused by erosion processes in these rivers which still show deposition tendencies, manifested by extensive areas which are contemporarily being filled in. It can be said therefore that the causes of the modifications of alluvial landscapes should be sought in contemporary tectonics. These processes are occurring at such a fast rate that the changes in the river regime from the deposition to the erosion regime, which should come as a consequence of such processes, are lagging behind.

The main rivers of this area include the Indus, Shyok and Zanskar. Their valleys, however, differ in character, although they share a similar tectonic base. The Indus valley has several terrace levels, covered in many places with huge alluvial cones formed at the entries of the tributary valleys, and its vast bottom is covered with meadows (occasionally wet), riverside scrub and crop cultivation.

The Shyok valley is as deep as the Indus valley, but its tributary valleys overhang its floor. The higher terraces can be found only locally and are occasionally covered by alluvial cones. The Shyok, flowing across a vast, plantless plain, is a braided river.

The Zanskar valley is the deepest, with steep slopes, no vegetation and a narrow floor. In a large part of its course, the river almost completely fills the valley floor, and where it widens it has a braided channel.

Except for the Indus valley which used to be grown with poplar and beech forests, this is an unwooded and nearly plantless country in most of its territory. These are conditions which prompt the development of eolian, erosion and deposition processes. The floor of the Shyok valley and the meadow terraces of the Indus are heavily windblown areas, and the generated, airborne material is then deposited in the form of dunes or eolian fields moving up the slopes, as high as the passes of the lower Ladakh range. Parts of the natural landscape of the forest layer of the Zanskar's northern slopes have been preserved only in some of the tributary valleys linked to the Indus river floor.

1983 saw the establishment of the Environmental Protection Institute in Leh. Instead of conducting research, the Institute promotes only those achievements of environmental sciences can be reasonably applied in the local landscape and amid the local community.

Ladakh follows the principle that preserving or restoring traditional forms of living, such as construction, clothing adapted to the local, harsh climatic conditions, natural forms of farming and cattle breeding, or crafts, is the best way to protect the environment. On the basis of such awareness-raising work, new and energy saving technologies (solar batteries, thermoinsulation) have been introduced. Another popularised issue is one of waste materials 
and clean potable water. In 1986, an international conference was organised in Leh to discuss these issues. In 1992, a special educational programme for children was developed, in addition to a scheme entitled 'Buddhism and ecology'. The Institutes publishes an annual information bulletin, and a conference summarising all the programmes run by the Institute is planned for 2020 .

English translation: Dorota Szmajda 


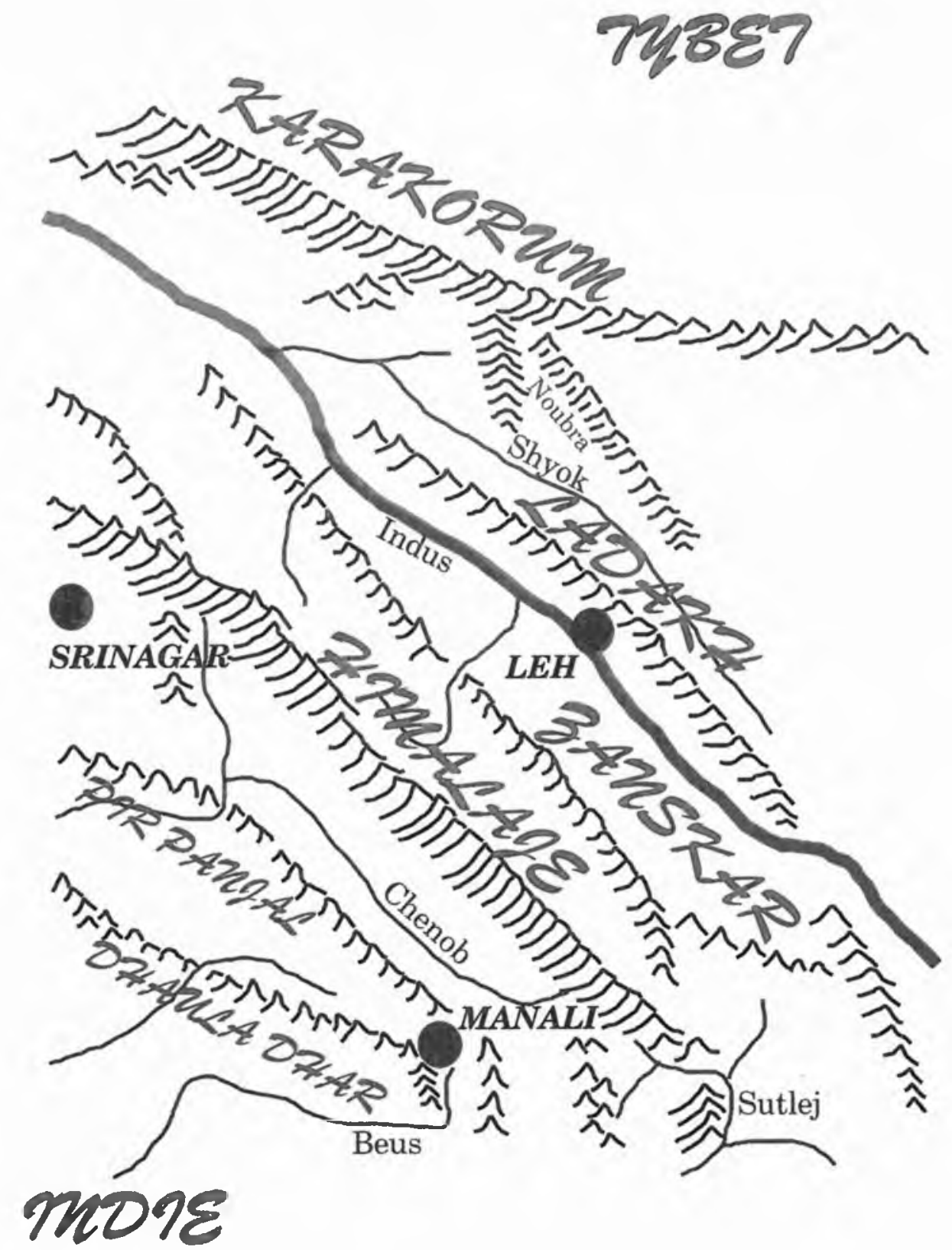

Fig. 1. Ladakh and Zanskar in the Himalaya System 


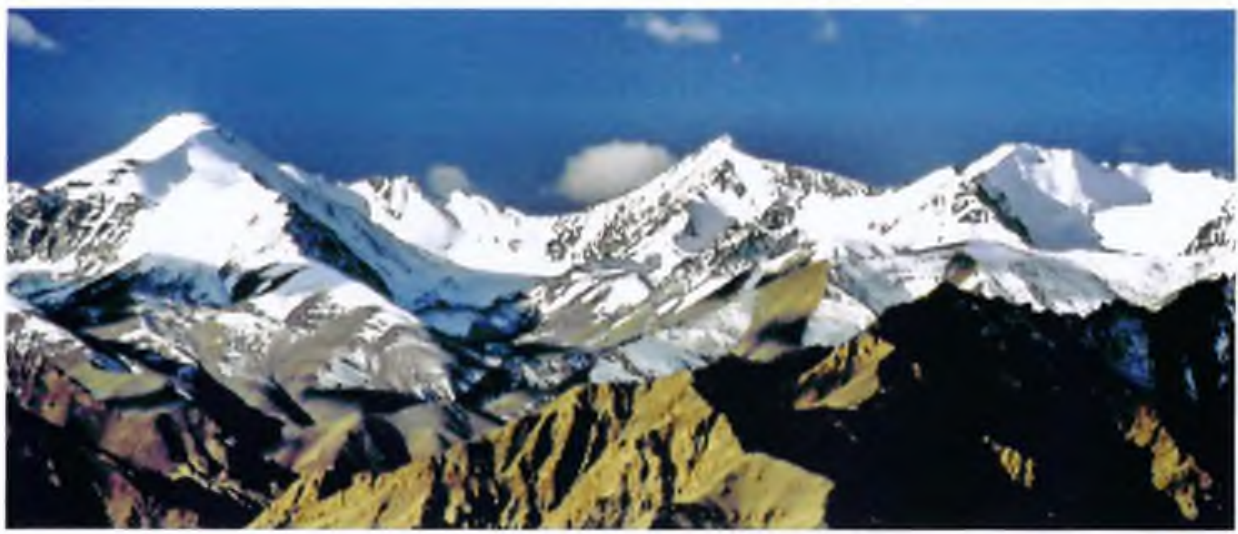

Photo 1. Panorama of the Zanskar mountains (Photo M. Zgorzelski)

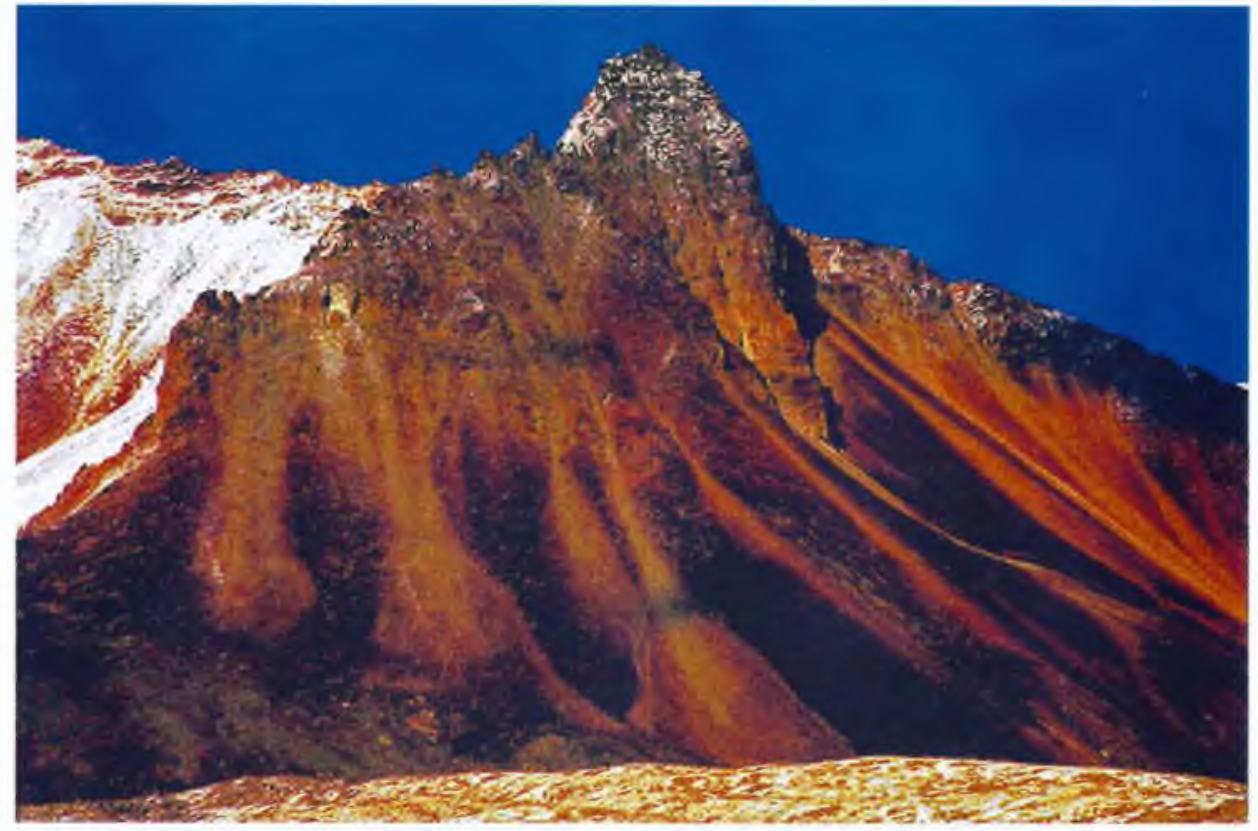

Photo 2. Mantle-rock on the slopes of Zanskar (Photo M. Zgorzelski) 


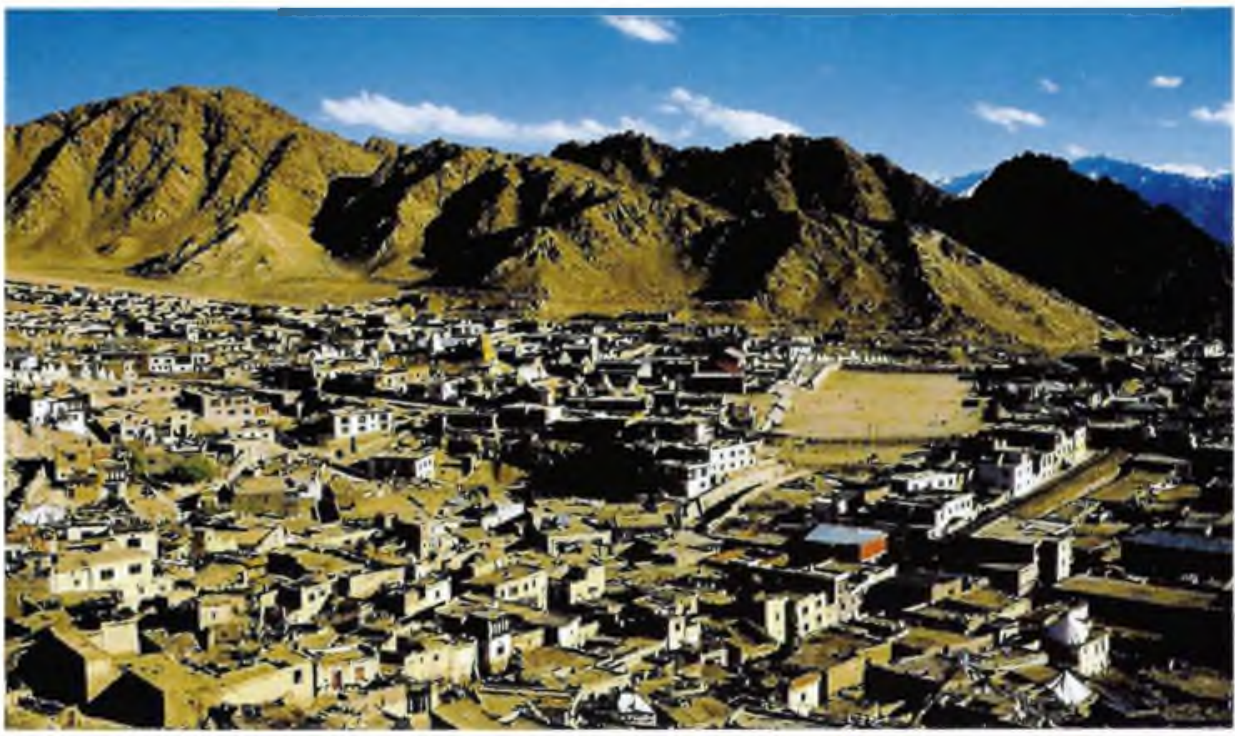

Photo 3. Leh, capital city of the Kingdom of Ladakh. In the backgrund, the Ladakh mountains (Photo M. Zgorzelski)

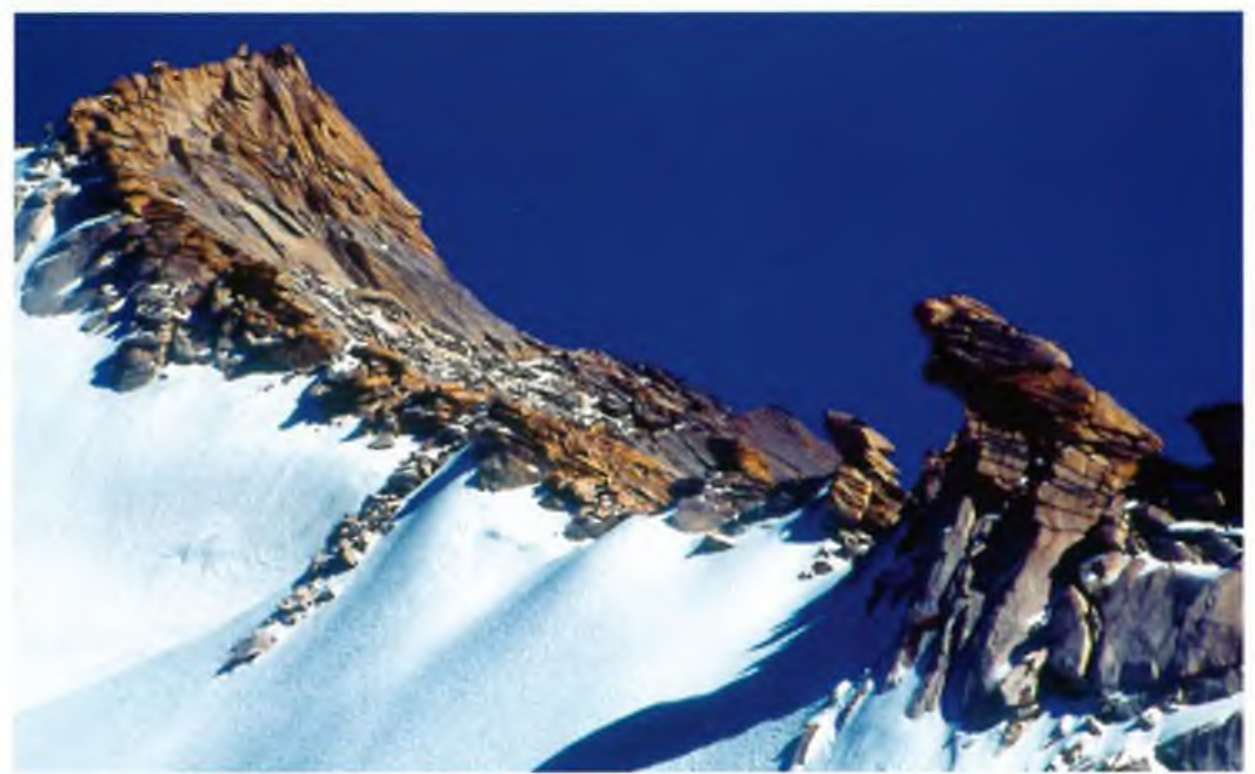

Photo 4. Summits of the highest Ladakh range (Photo M. Zgorzelski) 


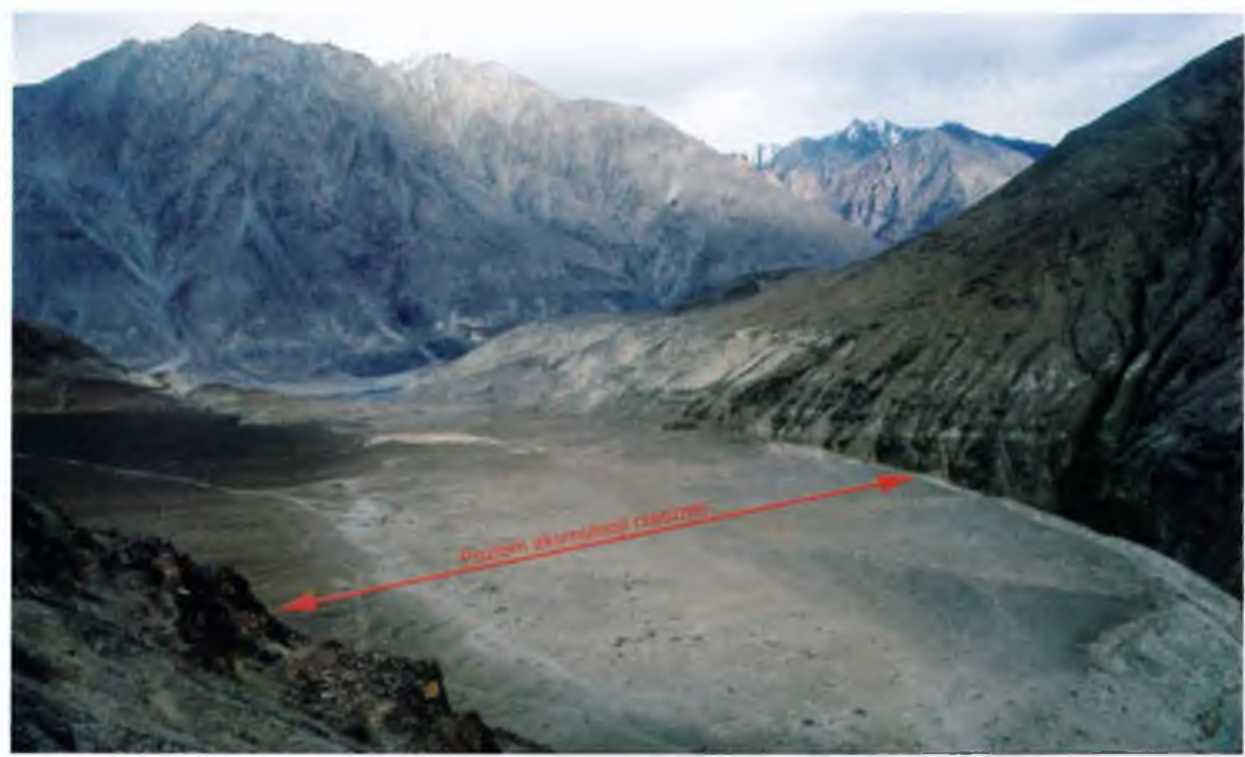

Photo 5. River deposits filling the Ladakh valleys, hanging several hundred metres over the bottom the tectonic valley of the Shyok river (Photo M. Zgorzelski)

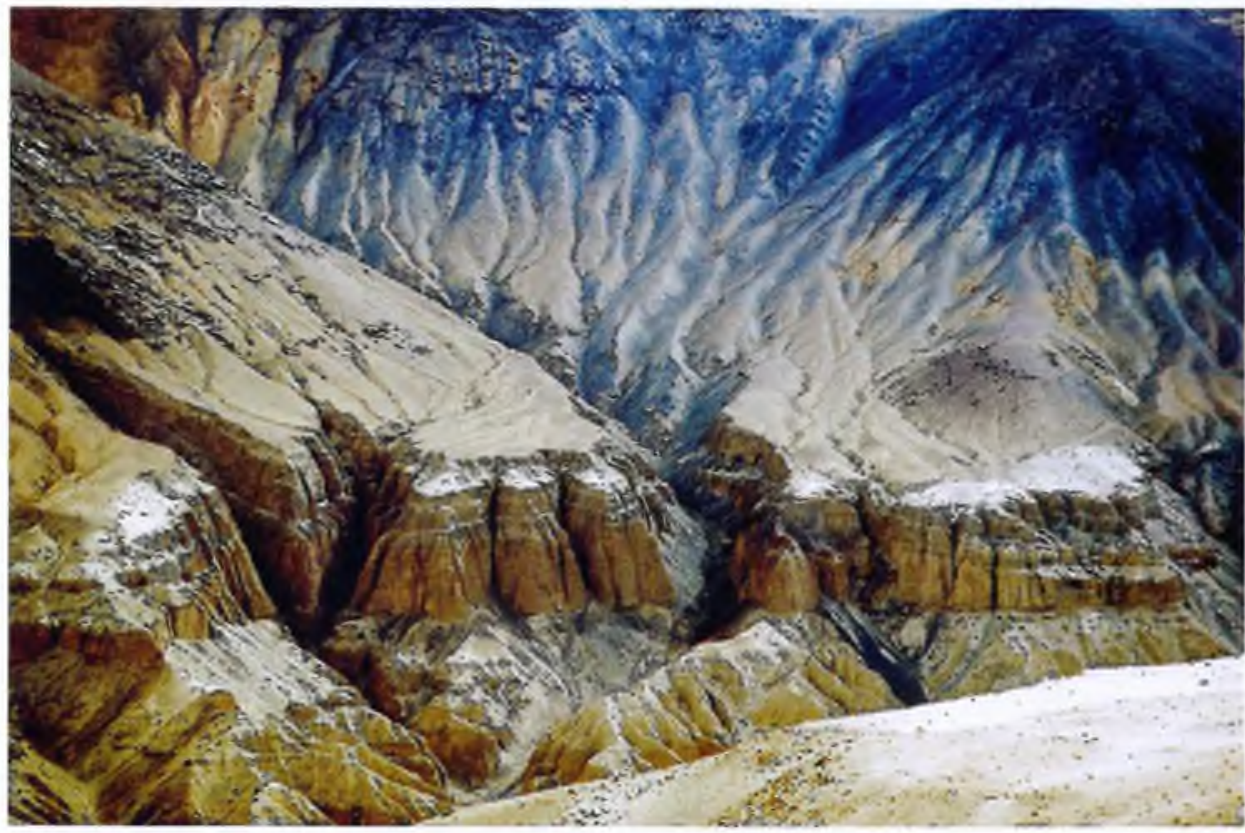

Photo 6. River deposits several hundred metres thick which fill the Ladakh Valleys (Photo M. Zgorzelski) 


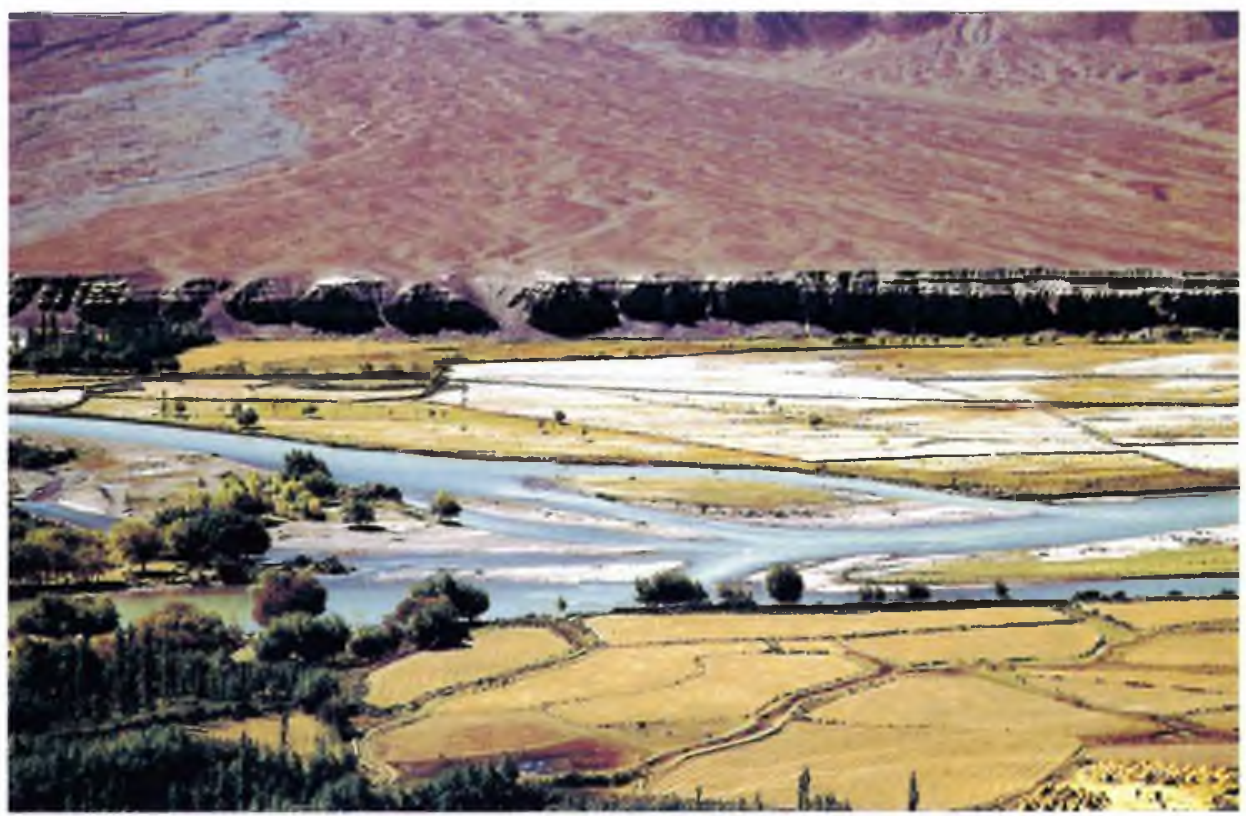

Photo 7. Bottom of the Indus valley (Photo M. Zgorzelski)

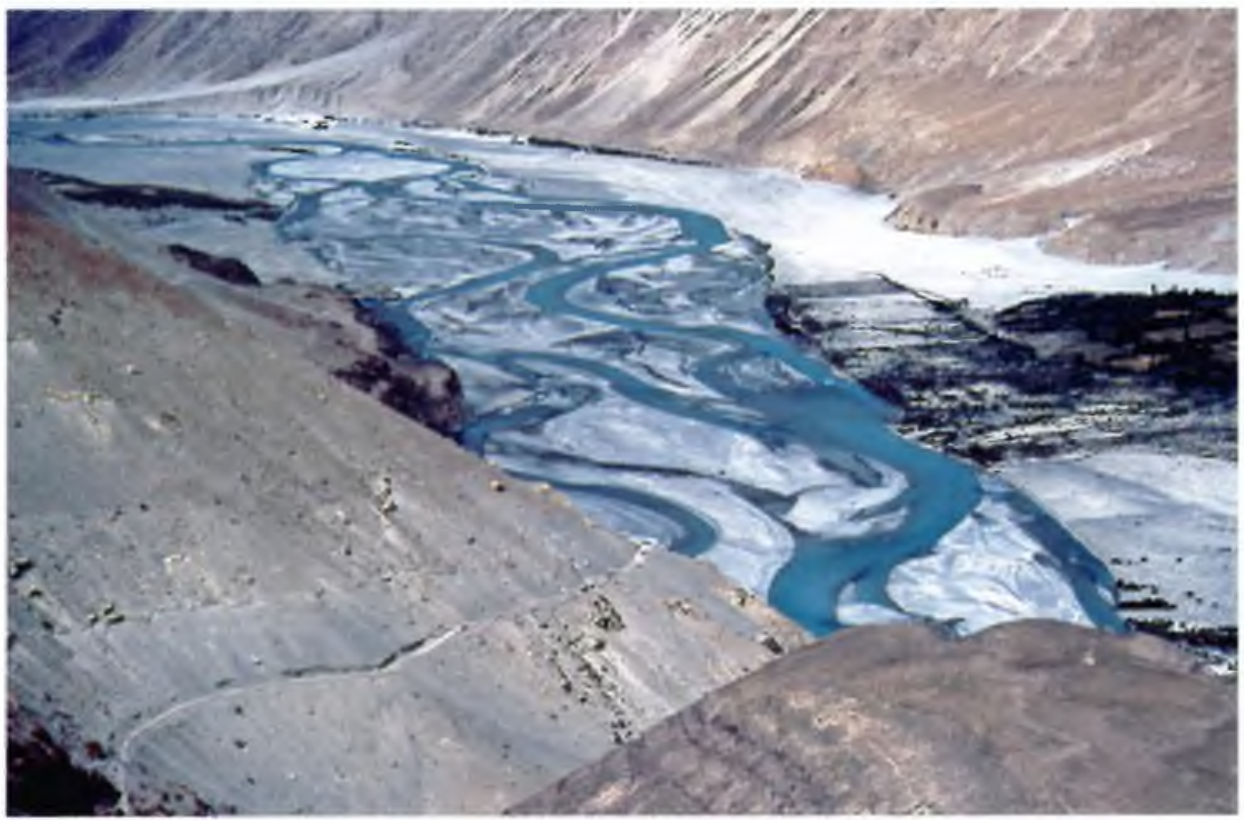

Photo 8. Bottom of the Shyok river valley (Photo M. Zgorzelski) 